\title{
Effect of the Free Over Fall Weirs Top Corners Curvatures on the Discharge Coefficient
}

\author{
Mohamed A. Ashour ${ }^{1}$, Khalid A.Amin ${ }^{2}$, Tarek S. Abu-Zeid ${ }^{3}$, Radwa Hassan ${ }^{4}$ \\ ${ }^{1,2,3}$ Department of Civil Engineering, Faculty of Engineering, Assiut University, 71515 Assiut, Egypt, \\ ${ }^{4}$ Water Holding Company, Assiut, Egypt
}

\begin{abstract}
In such a hard water situation in Egypt, in which we are facing a serious scarcity problem in our needs of water, we as water engineers have to adapt all the water measuring tools to perform accurate as maximum as possible. Since such tools are exciting everywhere along the very long, and complicated irrigation, and drainage systems on the network, in the forms of weirs, regulators, waterfalls, and others. The accuracy of such measuring structures is of great important in saving the water, and minimizing the overuse water. Owing to the simplicity, low cost, and its wide suitability for all types of waterways, we decided to investigate the clear over-fall weir as one of the most popular tools usually used for measuring the discharge in open channels. As the top edge geometry condition is an important parameter affecting the accuracy performance of such weirs, the present study investigates different top edges geometry conditions. Five shapes of the front weir top edge will be tested to point out the most effective shape in increasing the coefficient of discharge, and hence improving the discharge measuring efficiency. After that, the same tested edge shapes with the front edge, will be tested with the behind the top weir edge to fix the most compatible shapes may be used in both front, and behind top edges in achieving the optimum discharge measuring accuracy. An additional weir model with sharp edges in both fronts, and behind top edges will be tested under the same hydraulic conditions as a reference for comparison purposes. Experiments will be carried out using a horizontal testing laboratory flume $13.0 \mathrm{~m}$ long, $0.30 \mathrm{~m}$ wide, and $0.30 \mathrm{~m}$ height in the Irrigation laboratory of the Civil Engineering Department, Faculty of Engineering, Assiut university, Egypt.
\end{abstract}

Keywords: Clear over-fall weir, Weir top edge shapes, weir discharge coefficient.

\section{INTRODUCTION}

Egypt is facing most important problem nowadays, the decrease in irrigation water quantity, this problem may be resolved by optimizing our use of water to the maximum possible efficiency quantitatively and qualitatively. It may be achieved through constructing many of diversion head structures like a weir, dam, regulator which raising the upstream water level. Weirs are among the oldest and simplest hydraulic structures that have been used for centuries by hydraulic engineers for flow measurements, energy dissipation, regulation of flow depth, flood passage, distributing irrigation water, navigation and other means. So early, many researchers investigated different types, shapes, and arrangements of such weirs to evaluate its efficiency.

A weir is basically an obstruction across open channels for more than one technical purposes, such as measuring the discharge, modification the slopes of the ground to be suitable for constructing different types and degrees of open irrigation canals and drains, decreasing the static water pressure acting on some old regulators which proves some weekness, and in some cases weirs may be used as a sand and other sediment trap. A weir, as an obstruction, functions by causing water to rise above it to be flowing. The height of water over the weir sill correlates with the flow rate, so that measurement of the height of the flowing water above the top of the weir can be used to determine the flow rate by the use of an equation joining the effective hydraulic parameters (such as Water head, weir width, weir top corner shape, and roughness), This paper is a try to point out the most effective radius of curvature of the top edges in improving the coefficient of discharge of such widely used type of weirs. Five angles of curvatures of the front and the behind corners of the weir top will be examined, at the same time the sharp edged top will be also tested as a reference for comparison purposes with other tested rounded top corners. All examined models will be tested using discharge values ranging between 2.00 lit/sec and $22.0 \mathrm{lit} / \mathrm{sec}$, from a constant head laboratory elevated feeding tank. 
The literature includes great number of studies concerning improving the efficiency of weirs as a simple and accurate tool for measuring the flow in open channels. Weir shape, material, position, Top corners shape, top surface slope, upstream and downstream face slopes.

The present paper, as an approach to our coming paper, introduces an extensive reviewing of the most popular researches, and studies with their results and conclusions in addition to introducing a comparative study of such results obtained through all these researches, to be also compared with our obtained results from the present study.

In the present research our attention was given to investigate, the effect of modifying the geometrical shape of the weir top corners, on the discharge coefficient, and working efficiency of the weir.

\section{LITERATURE REVIEW}

Historically clear over-fall weirs were and still the most common structures used for measuring the discharge in open channels. Great numbers of scientists and researchers carried out a great number of investigations concerning the hydraulics of the clear over-fall weir, and its efficiency through studying all the effecting parameters., such as; Ashour [3], Cline [15], Herbert [25], Kindsvater [30], Leliavsky [31], Abou-Rehim [2], Borghei and et al. [8], Chatterjee and Ghosh [14], and others.

In this part, a comprehensive study and reviewing for the most important, and popular investigations carried out concerning the under-study topic, accompanied with the needed technical comments. At the same time, a technical comparison was done in a tabulated form, including all details such as the author name, investigation topic, tested shape, obtained results, and introduced equations if any.

Bazin [7] was the first to systematically investigate $C_{d}$ for embankment weirs. His tests included trapezoidal weirs with $\alpha_{\mathrm{o}}$ and $\alpha \mathrm{d}<45^{\circ}$, indicating a discharge reduction as the downstream weir face angle reduces. Three flow types were classified for embankment weirs: (1) free flow; (2) plunging nappe flow; and (3) submerged flow. Jaeger [26-27] used the Boussinesq equation to determine the discharge coefficient of circular-crested weirs. He stated that the discharge coefficient depends on the relative crest curvature $\mathrm{R} / \mathrm{H}_{\mathrm{w}}$ and the relative overflow depth $\mathrm{h} / \mathrm{H}_{\mathrm{w}}$. Both Hégly [22] and Jaeger [28] presented formulas for $\mathrm{C}_{\mathrm{d}}$ depending on $\mathrm{H}_{\mathrm{w}} / \mathrm{R}$.

The most common types of weirs are the sharp crested weir, the ogee crest weir and circular crested weir. Circular crested weirs are used for flow measurement and water level control in irrigation systems and reservoirs. The advantages of the circular crested weir compared to the other weirs include simplicity in design, stable overflow pattern, large coefficient of discharge, and associated low cost. The hydraulic characteristics of circular crested weirs have been studied by Hager [19, 20], Ramamurthy and et al., [40], Ramamurthy and Vo [38-39], Chanson [13], Heidarpour and et al., [24], Castro-Orgaz and et al., [11], Castro-Orgaz [10], Tadayon and Ramamurthy [44] and Mohammadzadeh Habili and Heidarpour [35]. Bagheri and Heidarpour [4] derived semi-empirical equations for normalized velocity profile and discharge coefficient of the circular crested weir. Also, Haghiabi [21], derived an equation (1) as follows, to determine the discharge coefficient of the circular crested weir, shown in the following fig. 1.

$C_{d}=2.787 \frac{z^{2}[\ln (z)]^{5 / 2}}{\left(\frac{z-1}{0.71}\right)^{2}\left(z^{2}-1\right)^{1 / 2}}$

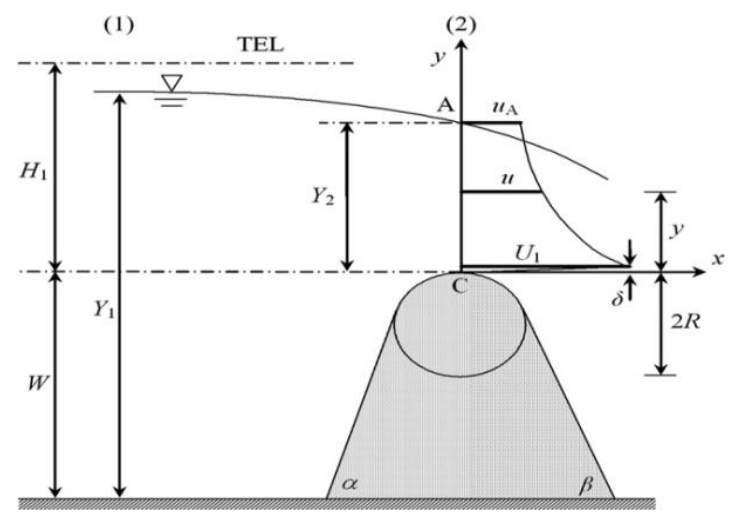

Fig1. Simple sketch of flow past a circular crested weir, Haghiabi [21]. 
Escande and Sananes [17] studied the discharge coefficient of the circular crested weirs with the upstream slope perpendicular to the bed and the downstream slope at an angle of $45^{\circ}$. The results indicated that, the discharge coefficient increases up to $15 \%$ or $20 \%$. Bos [9] used the available data and found out the relation between the discharge coefficient and $\left(\mathrm{H}_{\mathrm{w}} / \mathrm{R}\right)$ in circular crested weirs in both the downstream slope of $\left(\beta=45^{\circ}\right)$ and the upstream perpendicular slope as shown in fig. 2 . The discharge coefficient increased from 0.64 in $\left(\mathrm{H}_{\mathrm{w}} / \mathrm{R}\right)=0.05$ to 1.48 in $\left(\mathrm{H}_{\mathrm{w}} / \mathrm{R}\right)=5.5$, and for the larger values of $\left(\mathrm{H}_{\mathrm{w}} / \mathrm{R}\right)$, the discharge coefficient did not change any more in his research project. Ramamurthy's studies concentrated on the circular crested weirs with low heights weirs with upstream and downstream slopes of $63.41^{\circ}$. The range of his experiments was from $\left(\mathrm{H}_{\mathrm{w}} / \mathrm{R}\right)=0.8$ to $\left(\mathrm{H}_{\mathrm{w}} / \mathrm{R}\right)=$ 2.25 .

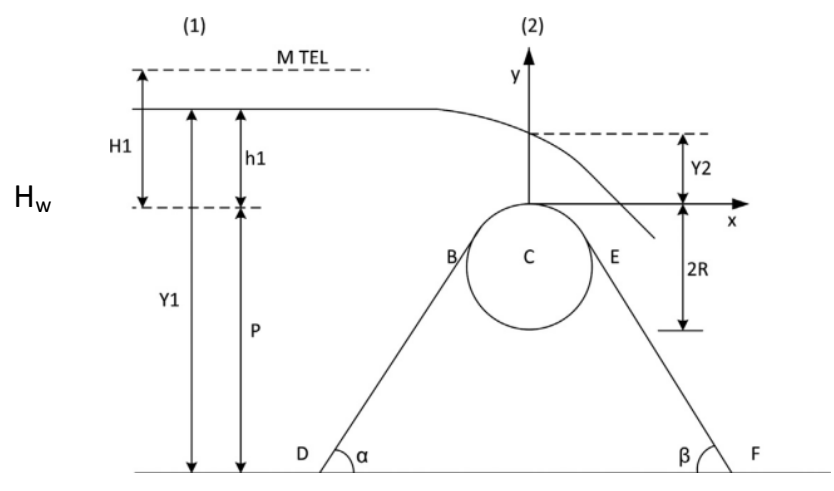

Fig2. The flow on the circular crested weir, Bos [9]

The effects of the upstream and downstream slopes on the discharge coefficient of the circular crested weirs were studied by Ramamurthy and Vo [39-40]. They tried to improve the discharge coefficient by providing different upstream and downstream slopes for circular-crested weirs, as shown in the following fig. 3. It is shown that, changing the upstream slope does not alter the weir-discharge coefficient. However, increasing the downstream weir slope appears to increase the discharge coefficient. Ramamurthy et. al. [41] studied the flow characteristics of rectangular broad-crested weirs with vertical upstream walls under free flow and submerged flow conditions. The study was focused on examining the effects of rounding of the upstream top corner of the weir on flow surface profile, bed pressure profile, and discharge characteristics. He gave a condition that the upstream corner of board crested weir is considered sharp if the radius of curvature at this corner is less than $9.4 \%$ of weir height.

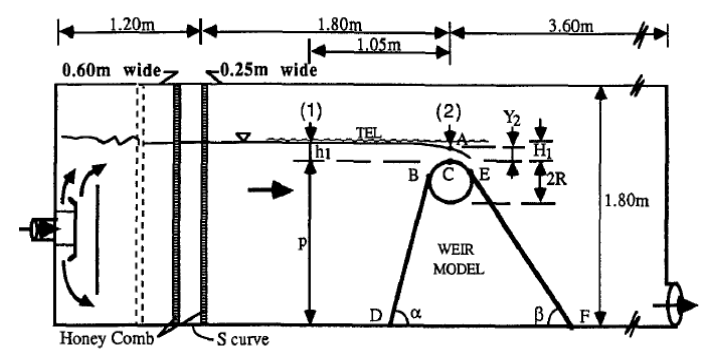

Fig3. The hydraulic parameters and the geometric form of circular crested weir, Ramamurthy and Vo. [39-40]

Mohammadzadeh-Habilin et al., [36], investigated experimentally a new weir entitled of quartercircular crested weir crest as shown in the following fig. 4. Results indicated that,the discharge coefficient of the weir is a constant value and equals to 1.261 . In the range of $\mathrm{H}_{\mathrm{w}} / \mathrm{R}=1.5$, it is more than the discharge coefficient of the circular crested weir.

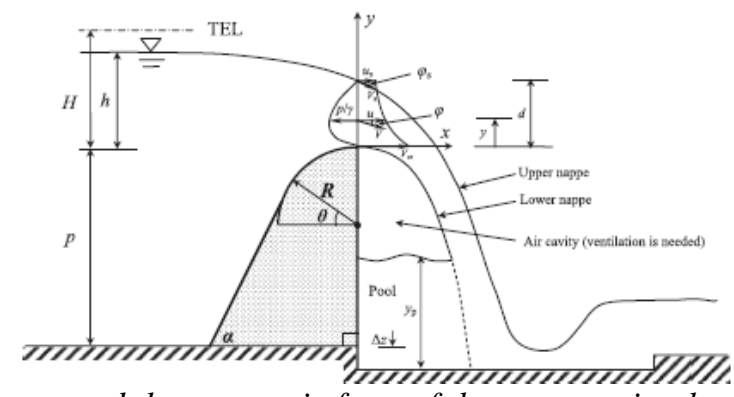

Fig4. The hydraulic parameters and the geometric form of the quarter-circular crested weir, MohammadzadehHabilin et al., [36]. 
Lukas et al [32], investigated experimentally the discharge coefficient for circular-crested weirs of various up and downstream weir face angles. Results showed that the upstream weir face angle $\left(\alpha_{o}\right)$ has only a small effect on the discharge coefficient,. In contrast, increasing the downstream weir face angle $(\alpha \mathrm{d})$ increases the discharge coefficient, as shown in the following fig. 5.

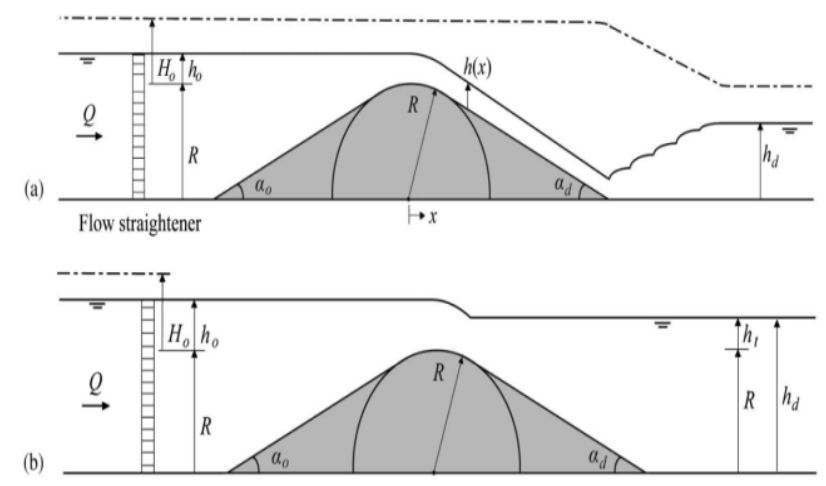

Fig5. Definition of flow geometry for (a) free; and (b) submerged overflow, Lukas et al [32]

The experiments of the study of Saied et al. [43], were carried out in the arch angels of $0^{\circ}, 30^{\circ}, 45^{\circ}$, $60^{\circ}$, and $90^{\circ}$ from the upstream crest as shown in the following fig. 6 . The results indicated that, the effects of the upstream crested arch on the discharge coefficient and energy loss had been negligible, and except for the arch angle of $0^{\circ}$, such effects upon the velocity distribution and the depth of the follow up on the crest of weir are not effective.

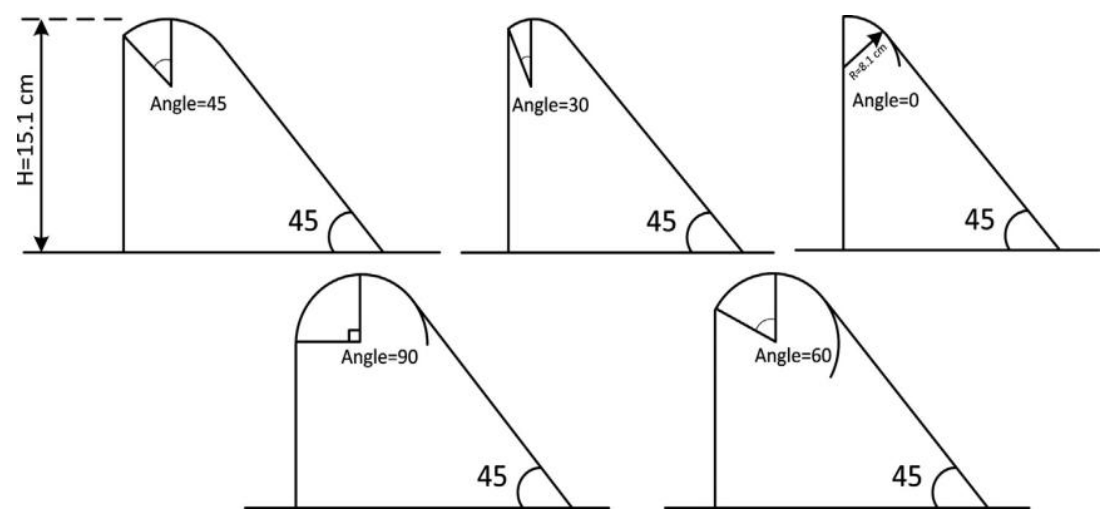

Fig6. The selected sections of the upstream crested arch, Saied et al. [45]

Noori and Juma [6], studied experimentally the performance of broad crested weir by introducing an upstream face slope, rounding the upstream corner and capping the upstream corner with a semicylinder in order to reduce the effect of flow separation. Mohamad et al., [34] observed that the curvature at the upstream edge of weir can be passed flow more easily and increased the discharge capacity, as shown in the following fig. 7.

1
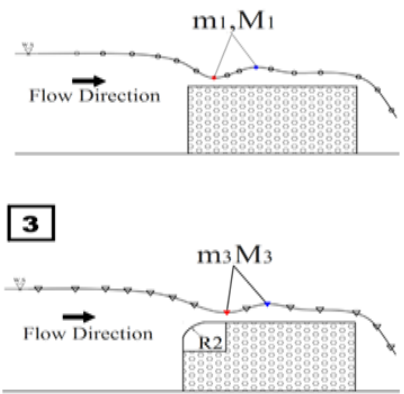

5

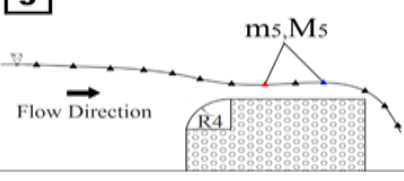

2

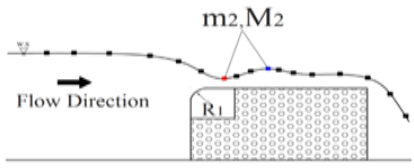

4

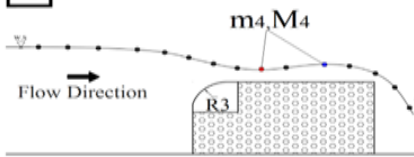

$1-5$

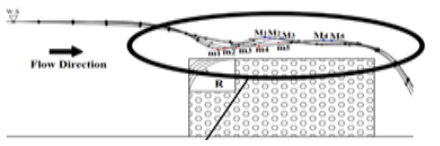

Fig7. The geometric form of circular crested weir, Mohamad et al., [34] 
Othman et al. [37], examined the effects of three different diameters of a cylindrical weir on the conditions of passing flows, as shown in the following photo 1 . Their results demonstrated that the effect of the discharge coefficient increases as the diameter of cylinder increases.
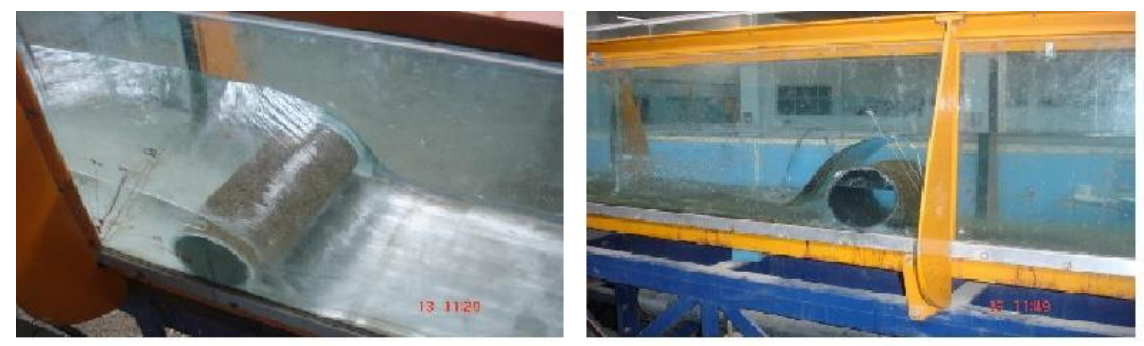

Photo1. The flow over the Weir, Othman et al [38]

Emad et al., [16] showed that the increase in the ratio of head to weir radius ratio $\left(\mathrm{H}_{\mathrm{w}} / \mathrm{R}\right)$ value as shown in the following fig. 8, causes an increase in discharge coefficient $\left(\mathrm{C}_{\mathrm{d}}\right)$ value for the same height of the weir. It was observed that the cylinder size (i.e. radius of cylindrical weir (R)) has an effect on the $\left(\mathrm{C}_{\mathrm{d}}\right)$. Abid Ali [1], used the finite element technique to study the characteristics of flow over round crested weirs placed normal to the channel axis. He studied three weir models with different height to base length ratios. He found that the discharge coefficient is a function of the geometrical dimensions of the weir and the upstream measured head.

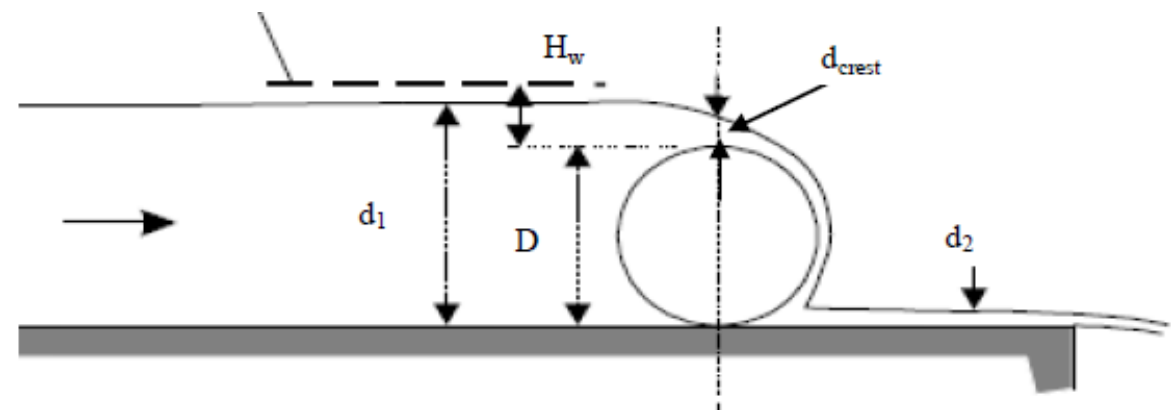

Fig8. A sketch of the circular weir shape, Emad et al., [16].

Chanson and Montes [12] studied the effects of the flow conditions upstream of the cylindrical weir on the discharge coefficient and they concluded that, the discharge coefficient is highly affected by the conditions upstream of the weir. Heidarpour and Chamani [23] using the flow function around the circular cylinder determined the velocity distribution on the crest and provided a mathematical model to determine the flow coefficient in circular crest weirs.

Chanson and Montes [12] carried out a comparison study between their work and the past investigation as shown in fig. 9 and table 1. The results showed that, a similar trend between their work and the re-analysis of VO's (1992) experiments, and some significant differences between the new set of data and some ancient investigations.

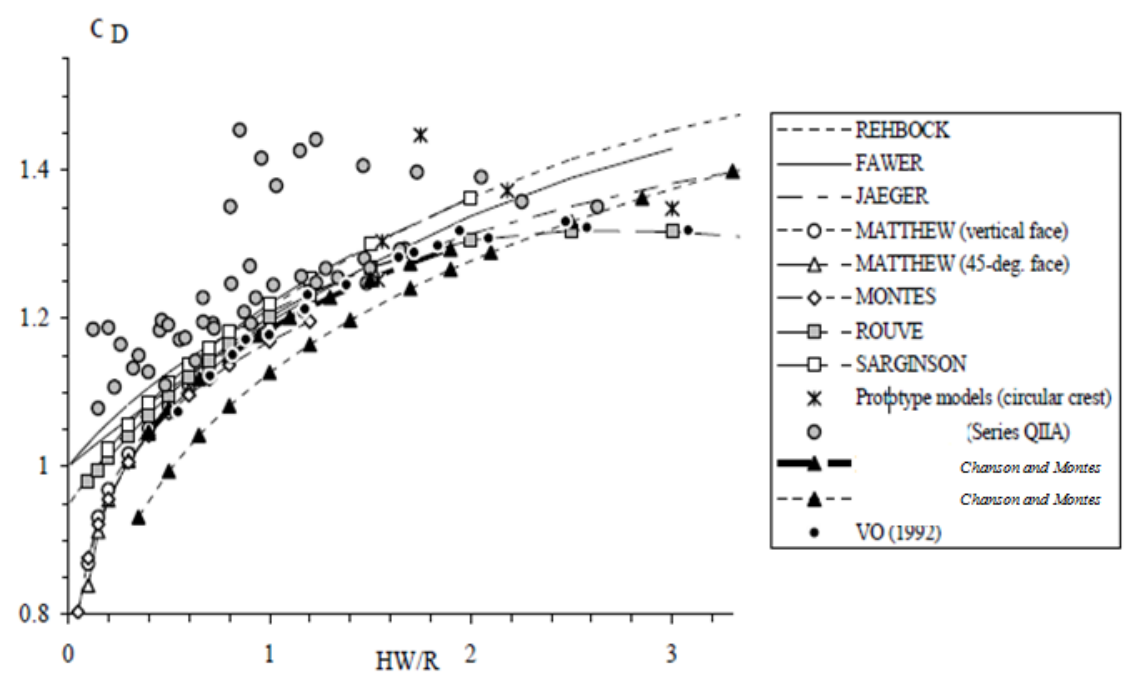

Fig9. Relationship between coefficient of discharge and the ratio of head to weir radius, Chanson and Montes [12] 
Table1. Empirical formulae of discharge coefficients above circular-crested weirs (laboratory studies and theoretical results)

\begin{tabular}{|c|c|c|}
\hline Reference & $C_{D}$ & Comments \\
\hline (1) & (2) & (3) \\
\hline REHBOCK (1929) & $0.552+0.177 \cdot \sqrt{30 \cdot\left(5 \cdot \frac{\mathrm{H}_{1}-\mathrm{z}_{\mathrm{dam}}}{\mathrm{R}}\right)^{2}}$ & $\begin{array}{l}\text { As given in SARGNSON } \\
\text { (1972). }\end{array}$ \\
\hline FAWER (1937) & $1+0.221^{*} \frac{\mathrm{H}_{1^{-2} \mathrm{dam}}}{\mathrm{R}} \cdot 0.0260 *\left(\frac{\mathrm{H} 1-\mathrm{z} \mathrm{dam}}{\mathrm{R}}\right)^{2}$ & Model data. \\
\hline JAEGER (1956) & $\frac{3}{2} \cdot\left(\frac{\mathrm{R}}{\mathrm{H}_{1^{-2} \mathrm{dam}}}+\frac{4}{3} \cdot \sqrt{\left(\frac{\mathrm{R}}{\mathrm{H}_{1^{-2} \mathrm{~d}}}\right)^{2}+\frac{4}{3} * \frac{\mathrm{R}}{\mathrm{H}_{1^{-2} \mathrm{dam}}}}\right)$ & $\begin{array}{l}\text { Theoretical result validated } \\
\text { with model data. }\end{array}$ \\
\hline \multirow[t]{3}{*}{ MATTHEW (1963) } & $1+0.230^{*} \frac{\mathrm{H}_{1-2 \mathrm{dam}}}{\mathrm{R}}-0.010 *\left(\frac{\mathrm{H}^{-2} \mathrm{dam}}{\mathrm{R}}\right)^{2}-0.0154^{*} \frac{\mathrm{R}}{\mathrm{H}_{1^{-2} \mathrm{dam}}}$ & Vertical upstream face. \\
\hline & $1+0.240^{*} \frac{\mathrm{H}_{1-\mathrm{z}} \mathrm{dam}}{\mathrm{R}}-0.028 *\left(\frac{\mathrm{H} 1-\mathrm{z} \mathrm{dam}}{\mathrm{R}}\right)^{2}-0.0184^{*} \frac{\mathrm{R}}{\mathrm{H}_{1^{-2} \mathrm{dam}}}$ & $\begin{array}{l}\text { Upstream face with } 45 \text {-degree } \\
\text { slope. }\end{array}$ \\
\hline & $1+0.240 * \frac{\mathrm{H}_{1}-\mathrm{z} \mathrm{dam}}{\mathrm{R}}-0.026 *\left(\frac{\mathrm{H} 1-\mathrm{z} \mathrm{dam}}{\mathrm{R}}\right)^{2}-0.0181 * \frac{\mathrm{R}}{\mathrm{H}_{1^{-1} \mathrm{dam}}}$ & $\begin{array}{l}\text { Upstream face with } 45 \text {-degree } \\
\text { slope. } D=0.0254 \mathrm{~m} \text {. }\end{array}$ \\
\hline MONTES (1964) & $1.169 \cdot\left(\frac{\mathrm{H}_{1-z_{\mathrm{dam}}}}{\mathrm{R}}\right)^{1 / 8}$ & $\begin{array}{l}\text { Re-analysis of data. } \\
0.05<\left(\mathrm{H}_{1}-\mathrm{z}_{\text {dam }}\right) / \mathrm{R}<1.2\end{array}$ \\
\hline SARGINSON (1972) & $\begin{array}{c}0.702+0.145^{*} \sqrt{33-\left(5.5-\frac{\mathrm{H}_{1^{-2} \mathrm{dam}}}{\mathrm{R}}\right)^{2}} \\
-3.146^{*} \frac{\sigma}{\rho_{\mathrm{w}}{ }^{*} \mathrm{~g}^{*}\left(\mathrm{H}_{1^{-2} \mathrm{dam}}\right)}\left(1-\left(1+1.2^{*} \frac{\mathrm{H}_{1^{-} \mathrm{d} \mathrm{dam}}}{\mathrm{R}}\right)^{-4 / 9}\right) \\
+0.160 * \frac{\mathrm{H}_{1^{-2} \mathrm{dam}}}{\mathrm{D}}\end{array}$ & $\begin{array}{l}\text { for } 0.034<\sigma<0.059 \mathrm{~N} / \mathrm{m} \\
\text { and }\left(\mathrm{H}_{1^{-}-\mathrm{d} \text { dam }}\right) / \mathrm{R}<2 \text { to } 4\end{array}$ \\
\hline $\begin{array}{l}\text { ROUVE and } \\
\text { INDLEKOFER (1974) }\end{array}$ & $\begin{array}{c}0.94440+0.35497 * \frac{\mathrm{H}_{1^{-2} \mathrm{dam}}}{\mathrm{R}}-0.10791 *\left(\frac{\mathrm{H}_{1^{-z} \mathrm{dam}}}{\mathrm{R}}\right)^{2} \\
+0.010309 *\left(\frac{\mathrm{H}_{1^{-2} \mathrm{dam}}}{\mathrm{R}}\right)^{3}\end{array}$ & $\begin{array}{l}\text { Semicircular crest with } \\
\text { ventilated nappe. } \\
\text { for } \frac{\mathrm{H}_{1^{-z}} \text { dam }}{R}<4.0\end{array}$ \\
\hline
\end{tabular}

\section{Comparsion between the Most Popular Works Concerninig the Discharge COEFFICIENT $\left(\mathbf{C}_{\mathrm{d}}\right)$ FOR WEIRS}

By reviewing the literature concerning the discharge coefficient $\left(\mathrm{C}_{\mathrm{d}}\right)$ for weirs, it was noticed that, many authors carried out many researches using many shapes of weirs and introduced some equations and relationships from which the discharge coefficient $\left(\mathrm{C}_{\mathrm{d}}\right)$ value can be estimated.

For the comparison purpose, the following values of the most effective parameters were assumed to estimate the discharge coefficient $\left(\mathrm{C}_{\mathrm{d}}\right)$ value using the introduced equations by different authors: $\left(\mathrm{H}_{\mathrm{w}} / \mathrm{R}=0.0,0.5\right)$

Table (2) introduces a compact summary of the most popular methods investigated by many authors and their predicted relations and equations for determining the discharge coefficient $\left(\mathrm{C}_{\mathrm{d}}\right)$ value. For the comparison purpose, the last column of that table presents the percentage of increase in the discharge coefficient value according each of the tabulated authors. From such an introduced comparative analysis, it is clear that research work given by Bahzad and Rondik [5] was the most efficient method of increseing the discharge coefficient value. While the study given by Mathew [33] was the lowest efficient method. The calculations showed that, the studies of Rehbock [41], Fawer [18], Jeager [29], and Rouve and Indelkofer [42] have nearly the same trend: i.e., the discharge coefficient increases with increasing dimensionless head on crest, and $\left(\mathrm{C}_{\mathrm{d}}\right)$ is larger than unity except for very low overflows $\left(\mathrm{H}_{\mathrm{w}} / \mathrm{R}<0.5\right)$.

Any discrepancy between the results of the previous mentioned studies are mainly due to the difference in the type of weir and the different experimental conditions. For all of the tabulated 
Effect of the Free Over Fall Weirs Top Corners Curvatures on the Discharge Coefficient

methods, there was a good agreement between the measured values and the theoretical ones for the mentioned equations.

Table2. The most popular investigated methods for determining the discharge coefficient $(\mathrm{Cd})$ for weirs and comparative analysis of its efficiency

\begin{tabular}{|c|c|c|c|c|}
\hline Reference & Equation & $\begin{array}{l}\text { Definition sketch } \\
\text { for shapes of } \\
\text { weirs }\end{array}$ & $\begin{array}{c}\text { The discharge } \\
\text { coefficient }(\mathrm{Cd}) \\
\text { value }\end{array}$ & $\begin{array}{l}\text { Percentage } \\
\text { of increase } \\
\text { in }(\mathrm{Cd})\end{array}$ \\
\hline $\begin{array}{c}\text { Bahzad } \\
\text { and Rondik } \\
\text { [5] }\end{array}$ & $\begin{array}{c}C_{M}=0.4134 \frac{F r_{1}^{0.207}}{\left(\frac{h_{1}}{p}\right)^{0.506}} \\
C_{M}=0.471 \frac{F r_{1}^{0.1}}{\left(\frac{h_{1}}{p}\right)^{0.314}\left(\frac{h_{1}}{r}\right)^{0.021}}\end{array}$ & & $\begin{array}{l}\left(\mathrm{C}_{\mathrm{d}}\right)_{(\mathrm{Hw} / \mathrm{R}=0.5)}=1.15 \\
\left(\mathrm{C}_{\mathrm{d}}\right)_{(\mathrm{Hw} / \mathrm{R}=0.0)}=0.89\end{array}$ & $29.21 \%$ \\
\hline $\begin{array}{c}\text { Fawer } \\
\text { [18] }\end{array}$ & $1+0.221 * \frac{\mathrm{HW}}{\mathrm{R}} \cdot 0.0260 *\left(\frac{\mathrm{HW}}{\mathrm{R}}\right)^{2}$ & $\left.\right|_{1 / 1} ^{7}$ & $\begin{array}{l}\left(\mathrm{C}_{\mathrm{d}}\right)_{(\mathrm{Hw} / \mathrm{R}=0.5)}=1.104 \\
\left(\mathrm{C}_{\mathrm{d}}\right)_{(\mathrm{Hw} / \mathrm{R}=0.0)}=1.00\end{array}$ & $10.4 \%$ \\
\hline $\begin{array}{c}\text { Jeager } \\
\text { [29] }\end{array}$ & $\frac{3}{2} *\left(\frac{\mathrm{R}}{\mathrm{HW}}+\frac{4}{3} \cdot \sqrt{\left.\left(\frac{\mathrm{R}}{\mathrm{HW}}\right)^{2}+\frac{4}{3} * \frac{\mathrm{R}}{\mathrm{HW}}\right)}\right.$ & 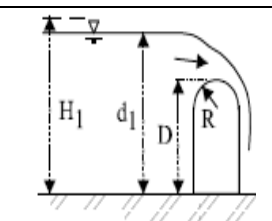 & $\begin{array}{l}\left(\mathrm{C}_{\mathrm{d}}\right)_{(\mathrm{Hw} / \mathrm{R}=0.5)}=1.13 \\
\left(\mathrm{C}_{\mathrm{d}}\right)_{(\mathrm{Hw} / \mathrm{R}=0.0)}=1.00\end{array}$ & $13 \%$ \\
\hline [33] & $1+0.230 * \frac{\mathrm{HW}}{\mathrm{R}} \cdot 0.010 *\left(\frac{\mathrm{HW}}{\mathrm{R}}\right)^{2} \cdot 0.0154 \frac{\mathrm{R}}{\mathrm{HW}}$ & $\overbrace{1 / 45 \text { deg. }}^{\pi}$ & $\begin{array}{l}\left(\mathrm{C}_{\mathrm{d}}\right)_{(\mathrm{Hw} / \mathrm{R}=0.5)}=1.081 \\
\left(\mathrm{C}_{\mathrm{d}}\right)_{(\mathrm{Hw} / \mathrm{R}=0.0)}=1.00\end{array}$ & $8.1 \%$ \\
\hline $\begin{array}{l}\text { Rehbock } \\
\text { [41] }\end{array}$ & $0.552+0.177 * \sqrt{30 \cdot\left(5 \cdot \frac{H W}{R}\right)^{2}}$ & 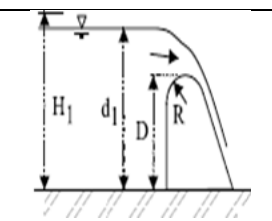 & $\begin{array}{l}\left(\mathrm{C}_{\mathrm{d}}\right)_{(\mathrm{Hw} / \mathrm{R}=0.5)}=1.07 \\
\left(\mathrm{C}_{\mathrm{d}}\right)_{(\mathrm{Hw} / \mathrm{R}=0.0)}=0.948\end{array}$ & $12.86 \%$ \\
\hline $\begin{array}{c}\text { Rouve and } \\
\text { Indelkofer } \\
\text { [42] }\end{array}$ & $\begin{array}{c}0.94440+0.35497 * \frac{\mathrm{HW}}{\mathrm{R}}-0.10791 *\left(\frac{\mathrm{HW}}{\mathrm{R}}\right)^{2} \\
+0.010309 *\left(\frac{\mathrm{HW}}{\mathrm{R}}\right)^{3}\end{array}$ & 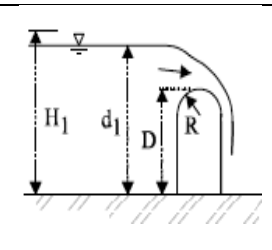 & $\begin{array}{l}\left(\mathrm{C}_{\mathrm{d}}\right)_{(\mathrm{Hw} / \mathrm{R}=0.5)}=1.098 \\
\left(\mathrm{C}_{\mathrm{d}}\right)_{(\mathrm{Hw} / \mathrm{R}=0.0)}=0.944\end{array}$ & $16.31 \%$ \\
\hline
\end{tabular}

Figure (10) shows the relationship between the coefficient of discharge $\left(\mathrm{C}_{\mathrm{d}}\right)$ and the ratio of head to weir radius $\left(\mathrm{H}_{\mathrm{w}} / \mathrm{R}\right)$. Firstly, this figure indicates a close agreement between past and new studies. And most of the data exhibit the same trend: i.e., the discharge coefficient increases with increasing dimensionless head on the crest $\left(\mathrm{H}_{\mathrm{w}} / \mathrm{R}\right)$, and $\left(\mathrm{C}_{\mathrm{d}}\right)$ is larger than unity except for very low overflows $\left(\mathrm{H}_{\mathrm{w}} / \mathrm{R}<0.25\right)$. Also, it is worth mentioning that Chanson and Montes [12] observed a maximum discharge coefficient for $\mathrm{H}_{\mathrm{w}} / \mathrm{R} \sim 1.5$ and, for larger ratios $\left(\mathrm{H}_{\mathrm{w}} / \mathrm{R}\right),\left(\mathrm{C}_{\mathrm{d}}\right)$ decreased and tended to sharpcrested weir values.

It is worth noting that, the discharge coefficient of (Mohammadzadeh-Habilin et al.[36]) is a constant value and equals to1.261. Also, this figure indicates that, for the same height of the weir, the increase in $\left(\mathrm{H}_{\mathrm{W}} / \mathrm{R}\right)$ value causes an increase in $(\mathrm{Cd})$ value, and the weirs of cylindrical shape performed better than those of sharp crest for any value of weir radius. 


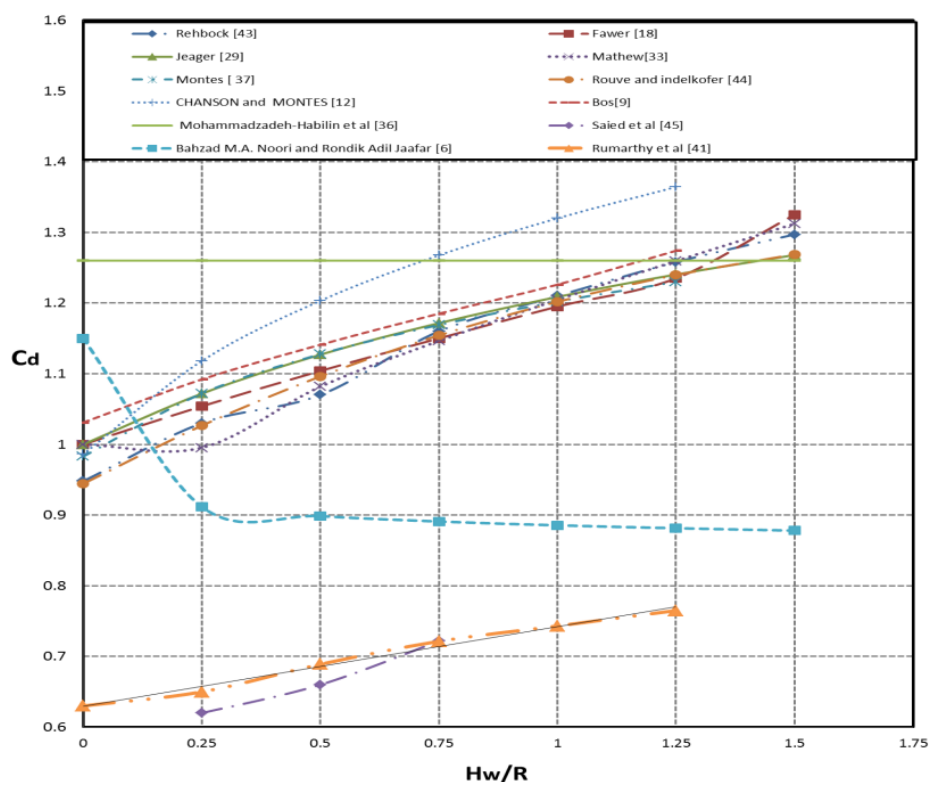

Fig10. Relationship between coefficient of discharge and the ratio of head to weir radius

\section{CONCLUSION}

From the present study, which reviewed the characteristics and efficiency of different types of weirs, a comparative study was done, from which we can conclude the following main points:

- The hydraulic characteristics of the circular crested weir depend only on the dimensionless total upstream head $\mathrm{H}_{\mathrm{w}} / \mathrm{R}$ and are independent of weir height.

- The presence of an upstream ramp has no effect on the discharge coefficient.

- The downstream weir face angle has a significant effect on the discharge coefficient.

- For a fixed downstream slope, the effect of upstream weir slope on $\left(\mathrm{C}_{\mathrm{d}}\right)$ is marginal. For a fixed upstream weir slope, $\left(\mathrm{C}_{\mathrm{d}}\right)$ increases when the downstream slope is increased.

- The cylinder weir size (i.e. radius of cylindrical weir $(\mathrm{R})$ ) has an effect on the discharge coefficient.

- The weirs of cylindrical shape performed better than those of sharp crest for any value of weir radius.

- For a given ratio head on crest to curvature radius $\left(\mathrm{H}_{\mathrm{w}} / \mathrm{R}\right)$, the largest discharge coefficient $\left(\mathrm{C}_{\mathrm{d}}\right)$ is observed for inflow conditions with an upstream undular hydraulic jump and the smallest $\left(C_{d}\right)$ is obtained for inflow conditions with an upstream (normal) hydraulic jump.

- For the same discharge capacity $(\mathrm{Q})$ and the same total upstream head $(\mathrm{H})$, the larger coefficient of discharge causes reduction in the weir crest width (L). Reduction in both of the weir surface area and the weir width reduced the required materials for the weir constructing and finally reduced the weir costs.

- Using curved weir, causes significant increase in the discharge with lesser complications in design and placement

\section{REFERENCE}

[1] Abid Ali, H.S., (1989), "Characteristic of Flow Over the Round Crested Weirs", M.Sc. Thesis, dept. of Civil Eng., University of Basrah, Iraq.

[2] Abou-Rehim, M.A., (1991), "Flow Over Weirs with Practical Profile", Alexandria Engineering Journal, 30 (4).

[3] Ashour, M. A. (1974), "Effect of Surface Slope on the Ratio of Submersion for the Standing Wave Weir", M.Sc. Thesis, Faculty of Engineering, Assiut University, Egypt.

[4] Bagheri, S., \& Heidarpour, M. (2010), "Overflow characteristics of circular-crested weirs", Journal of Hydraulic Research, 48 (4), 515-520. 
[5] Bahzad M. A., Jaafar, \& Rondik Adil, (2011) "Crest Shape Effect on the Performance of Rectangular Side Weirs" Al-Rafadain Engineering Journal., 19 (5), p87-106. 20p.

[6] Bahzad M.A. Noori, \& Inam A.K. Juma (2009) "Performance Improvement of Broad Crested Weirs" Al-Rafidain Engineering Vol.17 No.2

[7] Bazin, H. (1898), "Expériences nouvelles sur l'écoulement en déversoir [New experiments on weir discharge]." Ann. Ponts Chaussées, 68 (2), 151-265 [in French].

[8] Borghei, S.M, \& Jalili, M.R. \& Ghodsian, M. (1999), "Discharge Coefficient of Subcritical Flow". J. of Hydraulic Engineering, ASCE, 125 (10), 1051-1056.

[9] Bos, M. G. (1978), "Discharge measurement structures", Wageningen, The Netherlands: Int. Institute for Land Reclamation and Improvement.

[10] Castro-Orgaz, O. (2009), "Bernoulli theorem, minimum specific energy, and water wave celerity in open-channel flow", Journal of Irrigation and Drainage Engineering, 132 (6), 773-778.

[11] Castro-Orgaz, O., Gira' ldez, J. V., \& Ayuso, J. L. (2008), "Critical flow over circular crested weirs", Journal of Hydraulic Engineering, 134 (11), 1661-1664.

[12] Chanson, H. \& Montes J.S. (1998), "Overflow characteristics of circular weir", Journal of Irrigation and Drainage Engineering 124 (3):152-162.

[13] Chanson, H. (2006), "Minimum specific energy and critical flow conditions in open channels", Journal of Irrigation and Drainage Engineering, 132 (5), 498-502.

[14] Chatterjee, S.S. \& Ghosh, S.N., (1980), "Submerged Horizontal Jet Over Erodible Bed", J. of Hyd. Div., ASCE, 106 (HY11), Proc. Paper 15820, PP. 1765-1782.

[15] Cline, C.G. (1935), "Discharge Formula and Tables for Sharp-Crested Suppressed Weirs", Trans ASCE. Vol 100, PP. 396-413.

[16] Emad A., \& Adnan A., \& Mohammad A., (2011), "Overflow Characteristic of Cylindrical Shape Crest Weirs Over Horizontal Bed", Tikrit Journal of Engineering Sciences, 18(4): 92-39.

[17] Escande L., \& Sananes. (1959), "Etudedesseuilsdeversantsa' fente aspiratrice (weirs with suction slots) ", JILa Houille Blanch, 14 (Suppl.B) :892-902.

[18] Fawer, C. (1937). "Etude de Quelques Ecoulements Permanents à Filets Courbes" ('Study of some Steady Flows with Curved Streamlines.') Thesis, Lausanne, Switzerland, Imprimerie La Concorde, 127 pages (in French).

[19] Hager, W. H. (1985), "Critical flow condition in open channel hydraulics", Acta Mechanica, 54, 157-179.

[20] Hager, W. H. (1995), "Discussion to characteristics of circular crested weirs", Journal of Hydraulic Engineering, 120 (12), 1494-1495.

[21] Haghiabi, A. H., (2012), "Hydraulic characteristics of circular crested weir based on Dressler theory", Lorestan University, Khorramabad 68149-84649, Iran bio systems Engineering 112, 328-334.

[22] Hégly, V. M. (1939), "Expériences sur l'écoulement de l'eau au-dessus et en dessous des barrages cylindriques [Discharge over and below cylindrical weirs]." Ann. Ponts Chaussées, 109 (9), 235-281 [in French].

[23] Heidarpour M, \& Chamani MR. (2006), "Velocity distribution over cylindrical weir" Journal of Hydraulic Research ;44 (5) : 708-711.

[24] Heidarpour, M., Mohammadzadeh Habili, J., \& Haghiabi, A. H. (2008), "Application of potential flow to circular-crested weir", Journal of Hydraulic Research, 46 (5), 699-702.

[25] Herbert Addison (1941) "Hydraulic Measurements" Chapman, London.

[26] Jaeger, C. (1933a), "Notes sur le calcul des déversoirs et seuils [Discharge calculations for weirs and sills]" Bull. Tech. Suisse Romande, 59 (13), 153-156 [in French].

[27] Jaeger, C. (1933b), "Notes sur le calcul des déversoirs et seuils [Discharge calculations for weirs and sills]" Bull. Tech. Suisse Romande, 59 (14), 166-169 [in French].

[28] Jaeger, C. (1940), "Erweiterung der Boussinesq'schen Theorie des abflusses in offenen gerinnen: Abflüsse über abgerundete wehre [Extension of the Boussinesq Theory for open channel flow: Flow over round-crested] 
[29] Jaeger, C. (1956). “Engineering Fluid Mechanics” Blackie \& Son, Glascow, UK, 529 pages.

[30] Kindsvater, C.E., and Carter, R.W., (1959), "Discharge Characteristics of Rectangular Thin-Plate Weirs," Transactions, ASCE, 124 (VI), Paper No. 3001, PP. 772-818.

[31] Leliavsky, S., (1959), "Irrigation and Hydraulic Design", Chapman and Hall Ltd. London, Vol. I.

[32] Lukas S. \& Berglind R. \& Halldórsdóttir \& Willi H. Hager, (2011), "Effect of Weir Face Angles on Circular-Crested Weir Flow", DOI: 10.1061/(ASCE)HY.1943-7900.0000346. (C) 2011 American Society of Civil Engineers

[33] Matthew, G.D. (1963). "On the Influence of Curvature, Surface Tension and Viscosity on Flow over Round-Crested Weirs” Proc. Instn. Civil. Engrs., London, Vol. 25, pp. 511-524. Discussion : 1964, Vol. 28, pp. 557-569.

[34] Mohamad R., \& Ali H.D., \& Davood F. (2013), "Control of undular weir flow by changing of weir geometry", Flow Measurement and Instrumentation 34: 160-167.

[35] Mohammadzadeh Habili, J., \& Heidarpour, M. (2010), "Discussion to turbulence modeling of flows over circular spillways", Journal of Irrigation and Drainage Engineering, 136 (12), 872.

[36] Mohammadzadeh-Habilin\& M.Heidarpour \& H.Afzalimehr (2013). "Hydraulic characteristics of a new weir entitled of quarter-circular crested weir", Flow Measurement and Instrumentation 33:168-178

[37] Othman Tahssen A. \& Khalil I. \& Chilmeran Ibrahim A. I. Al-Hafith, (2011), "Effect of Size and Surface Roughness of Cylindrical Weirs on Over Flow Characteristics", Al-Rafidain Engineering, 19(2).

[38] Ramamurthy, A. S., \& Vo, N. D. (1993a), “Application of Dressler theory to weir flow”, Journal of Applied Mechanics, 60, 163-166.

[39] Ramamurthy, A. S., \& Vo, N. D. (1993b), "Characteristics of circular crested weir", Journal of Hydraulic Engineering, 119 (9), 1055-1062.

[40] Ramamurthy, A. S., Vo, N. D., \& Vera, G. (1992), "Momentum model of flow past weir", Journal of Irrigation and Drainage Engineering, 118 (6), 988-994.

[41] Rehbock, T. (1929). "The River Hydraulic Laboratory of the Technical University of Karlsruhe" In Hydraulic Laboratory Practice, ASME, New York, USA, pp. 111-242.

[42] Rouve, G., and Indlekofer, H. (1974). "Abfluss über geradlinige Wehre mit halbkreissförmigemÜberfallprofil”" ('Discharge over Straight Weirs with Semicylindrical Crest.') Der Bauingenieur, Vol. 49,No. 7, pp. 250-256 (in German).

[43] Saeid S. \&Eghbal K. \& Ahmad R., (2013), "The effects of various upstream arches of crest of the circular crested weir on hydraulic parameters", Flow Measurement and Instrumentation 32: 103-106

[44] Tadayon, R., \& Ramamurthy, A. S. (2009), "Turbulence modeling of flows over circular spillways", Journal of Irrigation and Drainage Engineering, 135 (4), 493-498. 


\section{AUTHORS' BIOGRAPHY}

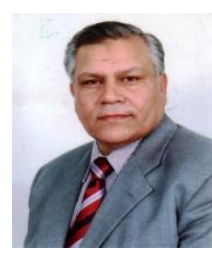

Mohammed A. Ashour, Prof. Civil Eng. Dept., Faculty of Engineering, Assiut University, Assiut, Egypt. He received the B.S. and M.S. degrees in Civil Engineering from the University of Assiut, Assiut, Egypt, in 1970, and 1974, respectively. He got the Ph.D. degree in Civil Engineering from Moscow Institute for Structural Engineering, Moscow, Russia, in 1979. He has many published papers in referred national and international journals and international conferences. His research interesting in: Scour, Energy dissipation, Stilling Basin, Sediment transport and hydraulic Structures. Supervising Master of Science and doctoral researchers.

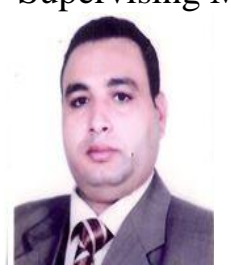

Khaled A. Amen, AssistantProf. Civil Eng. Dept., Faculty of Engineering, Assiut University, Assiut, Egypt. He received the B.S., M.S. and Ph.D degrees in Civil Engineering from the University of Assiut, Assiut, Egypt, in 1994, 1998 and 2006, respectively. His research interests are open channel hydraulics, stilling basins, sediment transport, simulation models, and artificial intelligence.

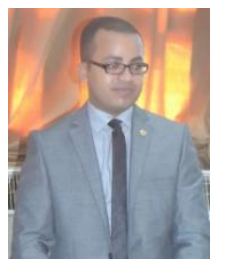

Dr. Tarek S. Abu-Zeid, received the M.Sc.and Ph.D degrees in civil engineering department from college of engineering, Assiut University, Assiut, Egypt in 2012 and2016 respectively. He is a lecturer with the Civil Engineering Department, Assiut University, Egypt. His research interests are open channel hydraulics, stilling basins, simulation models, and artificial intelligence.

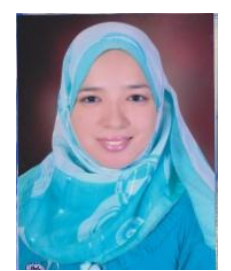

Eng. Radwa H. Hashem born in Assiut, Egypt, in 1989.She received the B.S. degree in Civil Engineering from the University of Assiut, Assiut, Egypt, in 2011. She isan engineering the Drinking Water Company in Assiut, Egypt, since 2015.His research interests are open channel hydraulics, and artificial intelligence. 